\title{
Process evaluation of the implementation of dementia-specific case conferences in nursing homes (FallDem): study protocol for a randomized controlled trial
}

Daniela Holle ${ }^{1,2^{*}}$, Martina Roes ${ }^{1,2}$, Ines Buscher ${ }^{1,2}$, Sven Reuther ${ }^{1,2}$, René Müller ${ }^{1}$ and Margareta Halek ${ }^{1,2}$

\begin{abstract}
Background: Challenging behaviors exhibited by individuals with dementia might result from an unmet need that they cannot communicate directly due to cognitive restrictions. A dementia-specific case conference represents a promising means of analyzing and exploring these unmet needs. The ongoing FallDem study is a stepped-wedged, cluster-randomized trial evaluating the effects of two different types of dementia-specific case conferences on the challenging behaviors of nursing home residents. This study protocol describes the process evaluation that is conducted, along with the FallDem study.

The goal of the process evaluation is to explain potential discrepancies between expected and observed outcomes, and to provide insights into implementation processes and recruitment strategies, as well as the contexts and contextual factors that promote or inhibit the implementation of dementia-specific case conferences.
\end{abstract}

Methods/Design: The process evaluation will use a mixed-method design comprising longitudinal elements, in which quantitative and qualitative data will be gathered. Qualitative data will be analyzed using content analysis, documentary analysis and a documentary method. Quantitative data (standardized questionnaires) will be analyzed using descriptive statistics. Both types of data will complement one another and provide a more comprehensive picture of the different objects under investigation.

Discussion: The process evaluation will allow for a comprehensive understanding of the changing processes and mechanisms underlying the 'black box' of the complex intervention of the FallDem study. These findings will provide practical knowledge regarding issues related to the implementation of dementia-specific case conferences in nursing homes.

Trial registration: Current Controlled Trials identifier: ISRCTN20203855, registered on 10th July 2013.

Keywords: Process evaluation, Stepped-wedged design, Implementation, Case conference, Dementia, Challenging behavior, Nursing home, mixed-method study

\footnotetext{
* Correspondence: daniela.holle@dzne.de

${ }^{1}$ German Center for Neurodegenerative Diseases (DZNE), Stockumer Str. 12, 58453 Witten, Germany

${ }^{2}$ School of Nursing Science, Witten/Herdecke University, Stockumer Str. 12, 58453 Witten, Germany
} 


\section{Background}

Living with dementia is complicated by the presence of behavioral and psychological symptoms, which are sometimes also referred to as challenging behaviors [1]. People with dementia residing in nursing homes frequently exhibit these challenging behaviors [2], which include wandering, physical aggression, screaming, depression and resistance to receiving help with activities of daily living [3]. Rather than cognitive dysfunction, functional impairment or physical dependence, these behaviors constitute one of the greatest burdens for professional caregivers in nursing homes [4]. Challenging behaviors of people with dementia can have multiple etiologies that differ among individuals and settings. According to the need-driven dementia-compromised behavior (NDB) model, these behaviors result from an unmet need, and if they are responded to appropriately, patients' quality of life will be enhanced [5]. A dementia-specific case conference represents a promising means of analyzing and exploring the unmet needs of people with dementia [6,7]. Two different approaches to the dementia-specific case conference have been most commonly described in the literature [8]. The first approach entails the use of an assessment instrument to systematically guide nursing staff through the diagnostic process of a case conference (WELCOME-IdA; Innovative dementia-oriented Assessment) $[9,10]$. The second approach involves the use of an open-thinking method to determine the potential triggers and causes of challenging behaviors rather than an assessment instrument (WELCOME-NEO) [11]. However, thus far, it is unclear whether the use of assessment instruments in dementia-specific case conferences are effective in supporting nursing teams in the diagnostic processes of need-driven behaviors [8]. Additionally, the advantages of dementia-specific case conferences using an open approach (without a standardized assessment) have not been explored in detail [12] or assessed in terms of their effectiveness.

The ongoing FallDem study (dementia-specific case conferences) is a stepped-wedged, cluster-randomized trial that aims to evaluate the uses of these two different types of dementia-specific case conferences (WELCOME-IdA and WELCOME-NEO) in 12 nursing homes [13]. This study is investigating whether these case conferences have an impact on residents' challenging behaviors (primary outcome), quality of life and psychotropic drug use, as well as on the burnout and work-related stress experienced by nursing staff and their vocational action competences (secondary outcomes).

Because an effectiveness study is limited in its ability to provide information regarding whether an intervention is successful [14,15], the FallDem study is being accompanied by a process evaluation, which is the main focus of the current study. A process evaluation provides insight into the so-called 'black box' of an effectiveness study and explains deviations between expected and observed outcomes. It further contributes to the understanding of how and to what extent an intervention is implemented in daily practice [16-19]. Furthermore, it provides information about the manner by which findings might be transferred across settings and populations $[17,20]$.

The process evaluation is of particular importance in the FallDem study because it is a dementia-specific case conference representing a complex intervention with interacting components [13] that will probably need time to be implemented in daily practice. It can be assumed that a dementia-specific case conference will have a delayed treatment effect [21] because teams in nursing homes have to learn how to employ it. This assumption needs to be further explored and defined in the process evaluation. Information about delayed treatment effects can subsequently aid in the design of a generalized linear mixed-effects model for the FallDem effectiveness study [13].

For the current study, the framework suggested by Grant et al. for designing process evaluations of clusterrandomized trials seems to be suitable because it considers 'delivery to clusters', the 'responses of individuals' and the 'responses of clusters' as essential domains to be studied [16]. These data can provide important evidence regarding the implementation success of an intervention [22]. Delivery to clusters includes information about how an intervention was delivered to each participating cluster and whether it was delivered as intended. Cluster variations in the delivery of an intervention might explain differences in its implementation and therefore variations in outcomes between clusters [16]. Response of individuals refers to the manners in which individuals in a target population react to a delivered intervention, for example, their attitudes, learning processes and behavioral changes [23]. If an intervention is not accepted by participants, the success of its implementation can be questioned [19]. Response of clusters describes how the intervention was adopted by each participating cluster. Differences in the adoption of clusters might also explain variations in outcomes [16].

The framework suggested by Grant et al. also includes the 'recruitment of clusters', 'recruitment and reach of individuals' and 'context' as areas to be studied in a process evaluation. These domains can help to assess the external validity of an effectiveness study [16]. Recruitment of clusters focuses on the strategies used by the research team to recruit clusters and the reasons why clusters decide (or not) to participate. Recruitment and reach of individuals describes the processes by which clusters identify and enroll individuals for an intervention and the proportion of recruited individuals who actually receive the intervention [16]. Information about recruitment 
and reach of clusters and individuals is important for deciding whether participants are representative of a target population [19]. A thorough description of the context in which a trial and intervention is embedded is of great importance for the generalization of findings, providing further relevant information about contextual factors that might act as barriers or facilitators to the implementation of the intervention [16,18], thereby impeding or strengthening its effects [17]. In summary, the framework suggested by Grant et al. [16] combines domains that are important for evaluating the implementation success of an intervention or that are crucial for judging the external validity of an effectiveness study, explaining why this specific framework was used to design the process evaluation of the FallDem study.

Due to the complexity of dementia-specific case conferences, a comprehensive implementation strategy has been developed based on expert consultation to support the cluster-randomized controlled trial, in which case conferences are employed in daily practice. This strategy follows a step-wise plan and consists of the following six components: (1) information about the research project and dementiaspecific case conferences, (2) kick-off meetings, (3) inservice training on dementia and moderator skills, (4) the establishment of a steering group, (5) reminders and (6) a telephone hotline (see Table 1). Although the effectiveness of the implementation strategy for the FallDem study will not be evaluated, knowledge about the usefulness of this strategy will be important for future implementations of dementia-specific case conferences in nursing homes. Therefore, four of the six domains of the process evaluation will be expanded to create a comprehensive implementation strategy, as shown in Figure 1.

Thus, thirteen research questions will guide the process evaluation, as shown in Table 2.

\section{Methods/Design Study design}

The process evaluation is a mixed-method study comprising longitudinal elements, for which quantitative and qualitative data are gathered (Tables 3 and 4). This method will be carried out alongside the FallDem study [13]) between September 2013 and March 2015. A total of 12 nursing homes (clusters) located in the area of North-RhineWestphalia (Germany) will take part in the process evaluation. The inclusion criteria for the clusters have been previously published elsewhere [13].

In the FallDem study, the intervention is rolled out every three months to two nursing homes (cluster group) over a period of 18 months (stepped-wedge design). Within every cluster, two nursing wards, which each include one nursing team (core team), participate in the intervention. The order in which the 12 nursing homes will receive the intervention and the type of intervention are determined at random (six WELCOME-IdA clusters and six WELCOME-NEO clusters). Two nursing teams that belong to one cluster will receive the same type of intervention to avoid contamination between WELCOMEIdA and WELCOME-NEO. The last group of clusters includes four instead of two clusters because two nursing homes functioning as cluster reserves will be dropped before the end of the study (Figure 2).

The intervention phase (in-service training during case conferences, on-the-job training and case conferences with support) for each cluster lasts seven months, after which a follow-up phase, which lasts until the end of the data collection period for all 12 clusters (T6), occurs. Hence, the intervention phase is the same duration for each nursing home, but the durations of the preintervention and follow-up phases differ (Figure 2).

\section{Intervention}

Dementia-specific case conferences are defined as structured, goal-directed, intra-professional conversational procedures that support the nursing staff in the descriptions and analyses of triggers and the causes of residents' challenging behaviors [6]. Dementia-specific case conferences are embedded within the general theory of hermeneutics and the NDB model [24,25]. Hermeneutics generally describes the philosophy of understanding and interpreting the social actions of individuals, groups and organizations [26]. Furthermore, using hermeneutics as a strategy to interpret observed behaviors strengthens the abilities of nursing teams to understand the perspectives of people with dementia with respect to their social or biographical backgrounds [24,27]. The NDB model applies a more specific theory that provides explanations for the reasons underlying the challenging behaviors exhibited by individuals with dementia. In the NDB model, challenging behaviors reflect the interactions of relatively stable background factors (such as neurological factors, health status, demographic and pre-morbid characteristics) with more changeable proximal factors (such as physiological and psychological needs and physical and social environments) that commonly result in need-driven behaviors [5] (Figure 3). Thus, the aim of a dementiaspecific case conference is to identify and analyze those background and proximal factors that commonly cause challenging behaviors in people with dementia.

WELCOME-IdA is a dementia-specific case conference that includes a comprehensive assessment system called IdA (Innovative dementia-oriented Assessment) [28]. IdA is based on the NDB model and comprises a two-step procedure. In the first step, the nursing staff is guided through a thorough description and quantification of a challenging behavior. In the second step, the nursing staff is guided through a search for potential triggers and causes of the challenging behavior. For this 


\section{Table 1 Components of intervention and implementation strategies}

\begin{tabular}{|c|c|c|c|c|}
\hline $\begin{array}{l}\text { Components of intervention } \\
\text { and implementation strategies }\end{array}$ & & Content & Participants (target population) & Duration \\
\hline \multirow[t]{3}{*}{ Components of the intervention } & $\begin{array}{l}\text { I. In-service training } \\
\text { in performing case } \\
\text { conferences }\end{array}$ & $\begin{array}{l}\text { - Aims and structures of CCS, NDB } \\
\text { model, communication rules and } \\
\text { use of IdA (only in the WELCOME-IdA } \\
\text { intervention group) }\end{array}$ & $\begin{array}{l}\text { - Manager of nursing home, } \\
\text { head nurses of nursing teams } \\
\text { and members of nursing teams } \\
\text { (core team) }\end{array}$ & - Half a day \\
\hline & $\begin{array}{l}\text { II. Case conferences } \\
\text { with support } \\
\text { (training on the job) }\end{array}$ & $\begin{array}{l}\text { - CCs are conducted with the support } \\
\text { of trainers; the trainers assist the } \\
\text { moderator, are involved in discussions } \\
\text { and provide advice }\end{array}$ & $\begin{array}{l}\text { - Members of nursing teams } \\
\text { (core teams) } \\
\text { and trainers }\end{array}$ & $\begin{array}{l}\text { - } 4 \text { CCs } \\
\text { within } 3 \text { months }\end{array}$ \\
\hline & $\begin{array}{l}\text { III. Case conferences } \\
\text { without support }\end{array}$ & - CCs are conducted without aid & $\begin{array}{l}\text { - Members of nursing teams } \\
\text { (core teams) }\end{array}$ & $\begin{array}{l}\text { - Minimum of } 4 \text { CCs } \\
\text { within } 4 \text { months }\end{array}$ \\
\hline \multirow[t]{7}{*}{ Components of implementation strategy } & $\begin{array}{l}\text { (1) Information about } \\
\text { project/case conferences }\end{array}$ & $\begin{array}{l}\text { - Information concerning the project/ } \\
\text { intervention and data collection, time } \\
\text { frame and organizational aspects }\end{array}$ & $\begin{array}{l}\text { - Manager of nursing home, } \\
\text { quality management and head } \\
\text { nurses of nursing teams }\end{array}$ & - 3 hours \\
\hline & (2) Kick-off meetings & $\begin{array}{l}\text { - Information concerning project/ } \\
\text { intervention and data collection, time } \\
\text { frame, and organizational aspects }\end{array}$ & - Nursing teams & • 1.5 hours \\
\hline & $\begin{array}{l}\text { (3) In-service training in } \\
\text { a) dementia and } \\
\text { challenging behaviors; and }\end{array}$ & $\begin{array}{l}\text { - a) Diagnosis of dementia, forms and } \\
\text { symptoms of dementia, causes of } \\
\text { challenging behaviors and their } \\
\text { management; and }\end{array}$ & - a) Nursing teams (core teams) & - a) Half a day \\
\hline & b) Moderation of case conferences & - b) Training in moderation techniques & - b) 2 persons from each nursing team & - b) 2 days \\
\hline & $\begin{array}{l}\text { (4) Establishment of } \\
\text { steering group }\end{array}$ & - Development of an implementation plan & $\begin{array}{l}\text { - Manager of nursing home, quality } \\
\text { management and members of both } \\
\text { nursing teams (core teams) }\end{array}$ & - 2 days \\
\hline & (5) Reminders & $\begin{array}{l}\text { - Reminders via telephone to conduct } \\
\text { CCs regularly }\end{array}$ & - All participants & - During intervention \\
\hline & (6) Telephone hotline & - Questions concerning CCS & - All participants & - During intervention \\
\hline
\end{tabular}



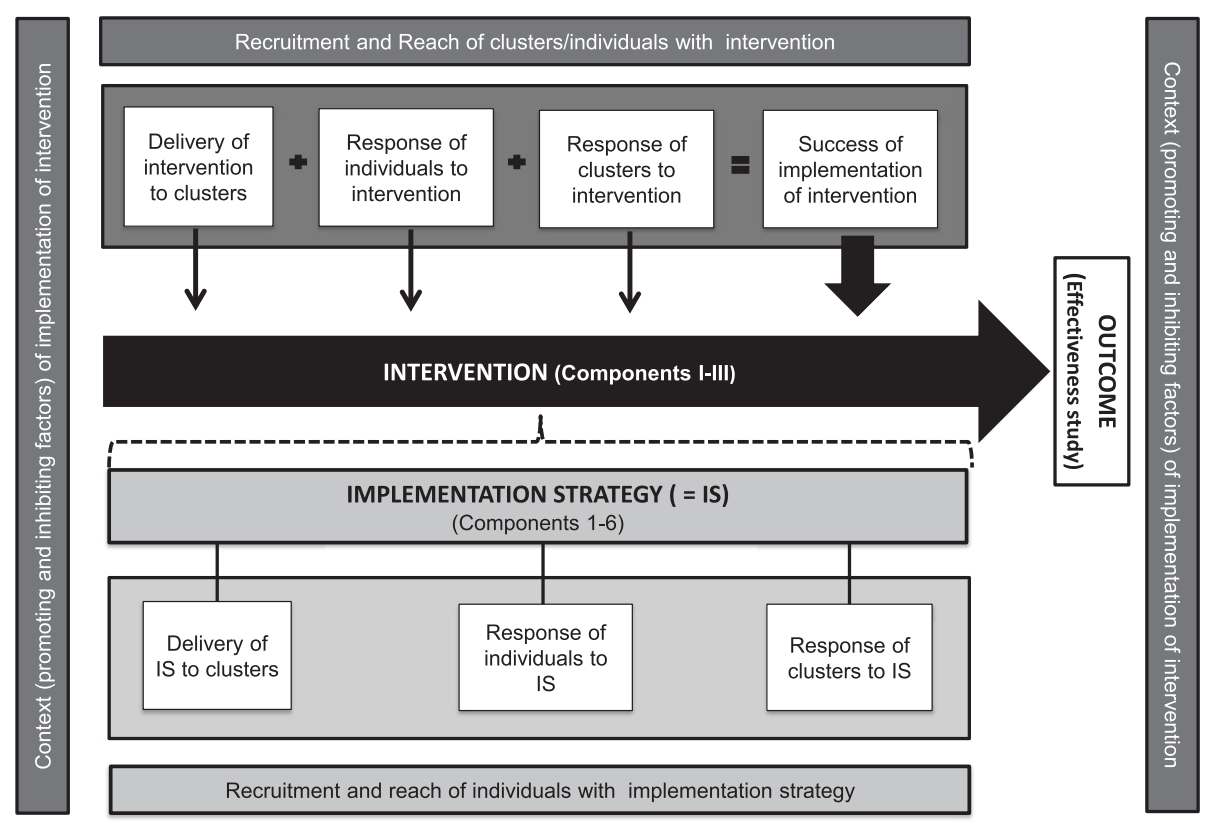

Figure 1 Domains of process evaluation.

second step, IdA provides five dimensions ('state of health and independence in everyday life', 'communication', 'personality and lifestyle before the onset of dementia', 'mood and emotions' and 'environmental influences') with specific guiding questions (Table 5).

WELCOME-NEO is a dementia-specific case conference that supports an open-thinking method. Therefore, it requires that the description and analysis of a challenging behavior be provided in a narrative manner, instead of relying on an assessment instrument for its description and quantification, as well as the determination of its potential triggers and causes (Table 5). Both types of dementia-specific case conferences have predefined process structures and key characteristics that are shown in Table 5.

The interventions of these two dementia-specific case conferences will begin with training in the respective model (WELCOME-IdA or WELCOME-NEO) and will be followed by four supported case conferences (on-thejob training). Then, a minimum of four dementiaspecific case conferences will be performed without any assistance (case conferences without support) by the nursing teams (Table 1 ).

Table 2 Research questions of process evaluation

\begin{tabular}{|c|c|c|}
\hline & Domain & Research question \\
\hline \multirow[t]{9}{*}{ Intervention } & Delivery to clusters & 1. Was the intervention delivered as intended to each nursing home (cluster)? \\
\hline & \multirow[t]{2}{*}{ Response of individuals } & 2. Which learning processes of the target population took place in response to the intervention? \\
\hline & & 3. What is the attitude of the target population toward the intervention? \\
\hline & Response of clusters & 4. How was the intervention adopted by each nursing home (cluster)? \\
\hline & \multirow[t]{2}{*}{ Recruitment of cluster } & 5. How were nursing homes (clusters) sampled and recruited for the FallDem study? \\
\hline & & 6. Why have the nursing homes participated (or not) in the FallDem study? \\
\hline & $\begin{array}{l}\text { Recruitment and reach } \\
\text { of individuals }\end{array}$ & $\begin{array}{l}\text { 7. How were participants in the intervention recruited by the cluster, and which individuals in the } \\
\text { target population actually received the intervention? }\end{array}$ \\
\hline & \multirow[t]{2}{*}{ Context } & 8. What is the context in which the intervention is being implemented? \\
\hline & & 9. What contextual factors promoted or inhibited the implementation of the intervention? \\
\hline \multirow{4}{*}{$\begin{array}{l}\text { Implementation } \\
\text { strategy }\end{array}$} & Delivery to clusters & 10. Was the implementation strategy delivered as intended for each nursing home (cluster)? \\
\hline & Response of individuals & 11. What is the attitude of the target population toward the implementation strategy? \\
\hline & Response of cluster & 12. How was the implementation strategy adopted by each nursing home (cluster)? \\
\hline & $\begin{array}{l}\text { Recruitment and reach } \\
\text { of individuals }\end{array}$ & $\begin{array}{l}\text { 13. How were the participants in the implementation strategy recruited by the nursing homes } \\
\text { (clusters), and which individuals in the target population actually received the implementation strategy }\end{array}$ \\
\hline
\end{tabular}


Table 3 Data collection for domains of intervention

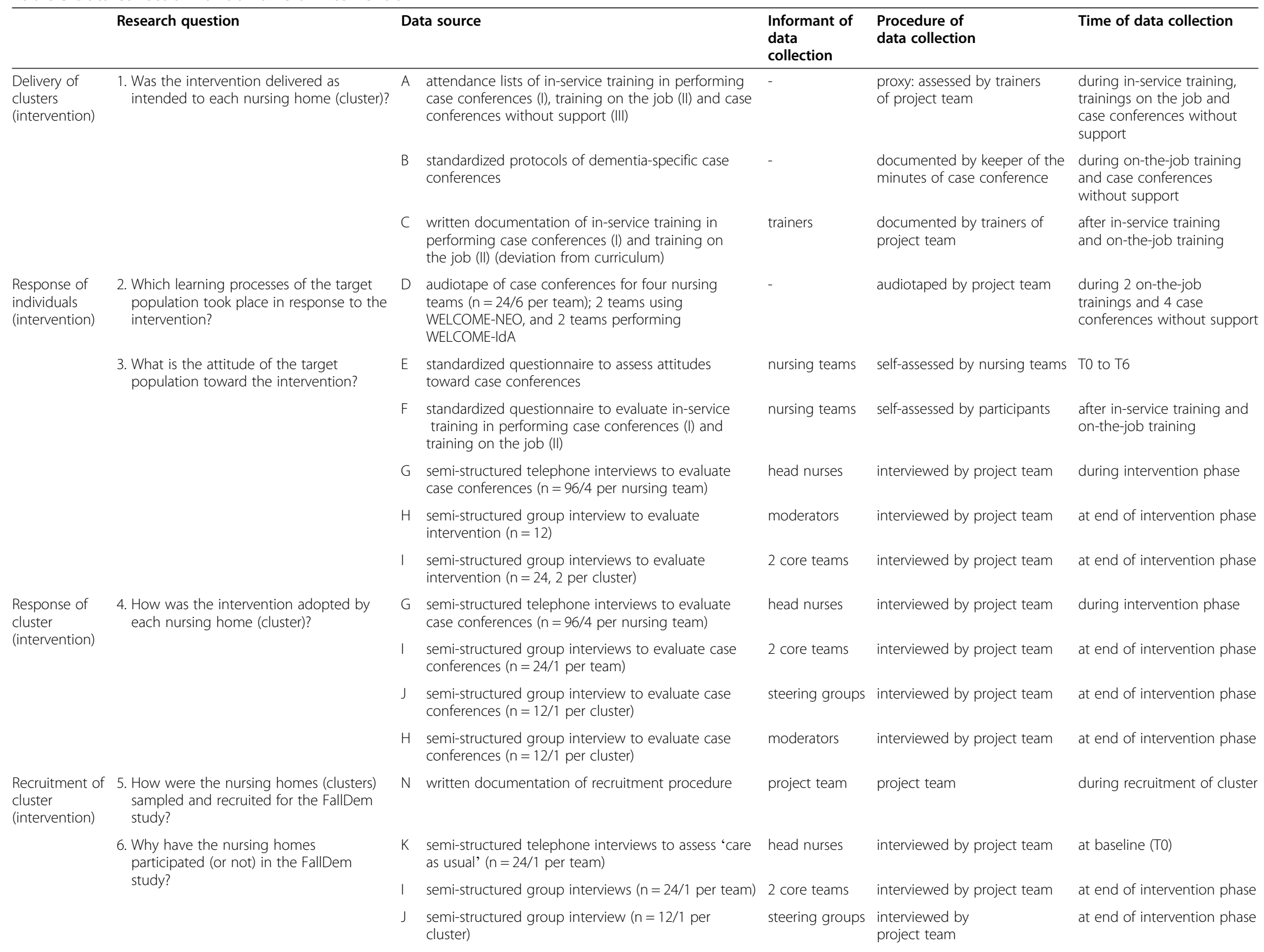


Table 3 Data collection for domains of intervention (Continued)

\begin{tabular}{|c|c|c|c|c|c|c|}
\hline \multirow[t]{3}{*}{$\begin{array}{l}\text { Recruitment } \\
\text { and reach of } \\
\text { individuals } \\
\text { (intervention) }\end{array}$} & $\begin{array}{l}\text { 7. How were the participants of the } \\
\text { intervention recruited by the cluster, and } \\
\text { who in the target population actually } \\
\text { received the intervention? }\end{array}$ & A & $\begin{array}{l}\text { attendance lists of in-service training in performing } \\
\text { case conferences (I), training on the job (II) and case } \\
\text { conferences without support (III) }\end{array}$ & - & $\begin{array}{l}\text { proxy: assessed by trainers of } \\
\text { project team }\end{array}$ & $\begin{array}{l}\text { during in-service trainings, } \\
\text { on-the-job trainings and } \\
\text { case conferences with } \\
\text { support }\end{array}$ \\
\hline & & J & semi-structured group interview $(n=12)$ & steering groups & interviewed by project team & at end of intervention phase \\
\hline & & $\mathrm{H}$ & semi-structured group interview $(n=12)$ & moderators & interviewed by project team & at end of intervention phase \\
\hline \multirow[t]{4}{*}{$\begin{array}{l}\text { Context } \\
\text { (intervention) }\end{array}$} & $\begin{array}{l}\text { 8. What is the context in which the } \\
\text { intervention is being implemented? }\end{array}$ & K & $\begin{array}{l}\text { semi-structured telephone interviews to assess 'care } \\
\text { as usual' }(n=24)\end{array}$ & head nurses & interviewed by project team & at baseline (T0) \\
\hline & & L & Dementia Milieu Assessment (DMA) & - & $\begin{array}{l}\text { proxy: assessed by project } \\
\text { team }\end{array}$ & T0 and T6 \\
\hline & & M & $\begin{array}{l}\text { standardized questionnaire to assess organizational } \\
\text { and structural characteristics of nursing home/ } \\
\text { nursing wards }\end{array}$ & $\begin{array}{l}\text { manager/head } \\
\text { nurses }\end{array}$ & $\begin{array}{l}\text { self-assessed by manager of } \\
\text { nursing homes/head nurses } \\
\text { of nursing wards }\end{array}$ & T0 to T6 \\
\hline & $\begin{array}{l}\text { 9. What contextual factors promote or } \\
\text { inhibit the implementation of the } \\
\text { intervention? }\end{array}$ & A- & all data assessed throughout process evaluation & - & - & - \\
\hline
\end{tabular}

A- all data assessed throughout process evaluation 


\begin{tabular}{|c|c|c|c|c|c|c|}
\hline & Research question & & ata source & Informant & Procedure of & Time of data \\
\hline $\begin{array}{l}\text { Delivery of clusters } \\
\text { (implementation strategy) }\end{array}$ & $\begin{array}{l}\text { 10. Was the implementation strategy delivered as intended to } \\
\text { each nursing home (cluster)? }\end{array}$ & A & $\begin{array}{l}\text { attendance lists of in-service trainings }(3 a, b) \\
\text { and steering group meetings (4) }\end{array}$ & - & $\begin{array}{l}\text { proxy: assessed by } \\
\text { teachers of } \\
\text { project team }\end{array}$ & $\begin{array}{l}\text { during } \\
\text { training and } \\
\text { meetings }\end{array}$ \\
\hline & & C & $\begin{array}{l}\text { written documentation of in-service training } \\
\text { (3a, b) and steering group meetings (4) (devi- } \\
\text { ation from curriculum) }\end{array}$ & trainers & $\begin{array}{l}\text { documented by } \\
\text { project team }\end{array}$ & $\begin{array}{l}\text { after training } \\
\text { and meetings }\end{array}$ \\
\hline $\begin{array}{l}\text { Response of individuals } \\
\text { (implementation strategy) }\end{array}$ & $\begin{array}{l}\text { 11. What is the attitude of the target population toward the } \\
\text { implementation strategy? }\end{array}$ & F & $\begin{array}{l}\text { standardized questionnaire to evaluate in- } \\
\text { service training (3a, b) and steering group } \\
\text { meetings (4) }\end{array}$ & $\begin{array}{l}\text { nursing } \\
\text { teams }\end{array}$ & $\begin{array}{l}\text { self-assessed by } \\
\text { participants }\end{array}$ & $\begin{array}{l}\text { after training } \\
\text { and meetings }\end{array}$ \\
\hline & & G & $\begin{array}{l}\text { semi-structured telephone interviews to } \\
\text { evaluate implementation strategy ( } n=96 / 4 \text { per } \\
\text { nursing ward) }\end{array}$ & head nurses & $\begin{array}{l}\text { interviewed by } \\
\text { project team }\end{array}$ & $\begin{array}{l}\text { during } \\
\text { intervention } \\
\text { phase }\end{array}$ \\
\hline & & I & $\begin{array}{l}\text { semi-structured group interviews to evaluate } \\
\text { case conferences ( } n=24 / 1 \text { per team) }\end{array}$ & core teams & $\begin{array}{l}\text { interviewed by } \\
\text { project team }\end{array}$ & $\begin{array}{l}\text { at end of } \\
\text { intervention } \\
\text { phase }\end{array}$ \\
\hline & & J & $\begin{array}{l}\text { semi-structured group interviews to evaluate } \\
\text { case conferences ( } n=12 / 1 \text { per cluster }\end{array}$ & $\begin{array}{l}\text { steering } \\
\text { groups }\end{array}$ & $\begin{array}{l}\text { interviewed by } \\
\text { project team }\end{array}$ & $\begin{array}{l}\text { at end of } \\
\text { intervention } \\
\text { phase }\end{array}$ \\
\hline & & H & $\begin{array}{l}\text { semi-structured group interview to evaluate } \\
\text { case conferences }(n=12 / 1 \text { per cluster) }\end{array}$ & moderators & $\begin{array}{l}\text { interviewed by } \\
\text { project team }\end{array}$ & $\begin{array}{l}\text { at end of } \\
\text { intervention } \\
\text { phase }\end{array}$ \\
\hline $\begin{array}{l}\text { Response of cluster } \\
\text { (implementation strategy) }\end{array}$ & 12. How was the implementation strategy adopted by each cluster? & G & $\begin{array}{l}\text { semi-structured telephone interviews to } \\
\text { evaluate implementation strategy ( } n=96 / 4 \text { per } \\
\text { nursing ward) }\end{array}$ & head nurses & $\begin{array}{l}\text { interviewed by } \\
\text { project team }\end{array}$ & $\begin{array}{l}\text { during } \\
\text { intervention } \\
\text { phase }\end{array}$ \\
\hline & & । & $\begin{array}{l}\text { semi-structured group interviews to evaluate } \\
\text { case conferences ( } n=24 / 1 \text { per team) }\end{array}$ & $\begin{array}{l}2 \text { core } \\
\text { teams }\end{array}$ & $\begin{array}{l}\text { interviewed by } \\
\text { project team }\end{array}$ & $\begin{array}{l}\text { at end of } \\
\text { intervention } \\
\text { phase }\end{array}$ \\
\hline & & $J$ & $\begin{array}{l}\text { semi-structured group interview to evaluate } \\
\text { case conferences ( } n=12 / 1 \text { per cluster) }\end{array}$ & $\begin{array}{l}\text { steering } \\
\text { groups }\end{array}$ & $\begin{array}{l}\text { interviewed by } \\
\text { project team }\end{array}$ & $\begin{array}{l}\text { at end of } \\
\text { intervention } \\
\text { phase }\end{array}$ \\
\hline & & $\mathrm{H}$ & $\begin{array}{l}\text { semi-structured group interview to evaluate } \\
\text { case conferences ( } n=12 / 1 \text { per cluster) }\end{array}$ & moderators & $\begin{array}{l}\text { interviewed by } \\
\text { project team }\end{array}$ & $\begin{array}{l}\text { at end of } \\
\text { intervention } \\
\text { phase }\end{array}$ \\
\hline $\begin{array}{l}\text { Recruitment and reach of } \\
\text { individuals } \\
\text { (implementation strategy) }\end{array}$ & $\begin{array}{l}\text { 13. How were participants of the implementation strategy (IS) } \\
\text { recruited by the nursing homes (clusters), and who in the target } \\
\text { population actually received the IS? }\end{array}$ & A & $\begin{array}{l}\text { attendance lists of in-service training }(3 a, b) \\
\text { and steering group meetings }(4)\end{array}$ & - & $\begin{array}{l}\text { proxy: assessed by } \\
\text { teachers of } \\
\text { project team }\end{array}$ & $\begin{array}{l}\text { during } \\
\text { training, } \\
\text { meetings }\end{array}$ \\
\hline & & $\mathrm{H}$ & semi-structured group interview $(n=12)$ & $\begin{array}{l}\text { steering } \\
\text { groups }\end{array}$ & $\begin{array}{l}\text { interviewed by } \\
\text { project team }\end{array}$ & $\begin{array}{l}\text { at end of } \\
\text { intervention } \\
\text { phase }\end{array}$ \\
\hline
\end{tabular}




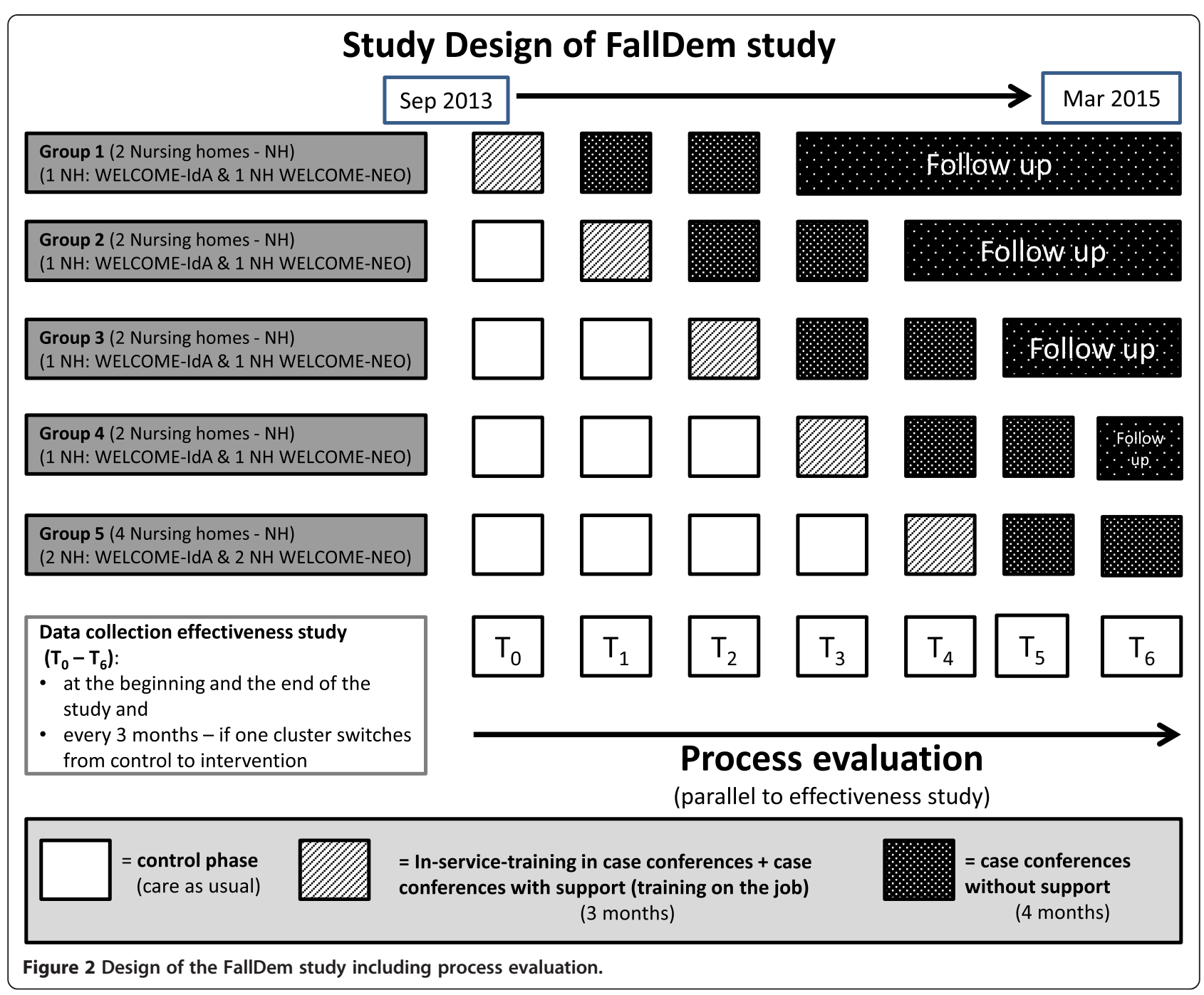

Implementation strategy

The comprehensive implementation strategy will follow a gradual plan consisting of six components as follows:

(1) Information about the research project and dementiaspecific case conferences: the implementation strategy will start with a detailed meeting (three hours) with representatives of the top management, quality management and nursing teams of each nursing home to discuss topics, including the key elements of the research project and dementia-specific case conferences.

(2) Kick-off meetings: following the meeting with the leaders, a kick-off meeting (one and a half hours) will be organized at each nursing home (cluster) to provide information to the participating nursing teams about the research project and dementiaspecific case conferences. A direct strategic communication to staff members of the nursing homes will demonstrate that the researchers value the decision to participate in the research project [29]. These meetings will be held with the general understanding that the implementation of the intervention requires communication through existing organizational channels and, over time, among the members of the nursing home staff [30].

(3) In-service training: the in-service training will comprise two modules, including 'dementia and challenging behavior' and 'moderator skills'. Previous studies have shown that significant knowledge about dementia and challenging behaviors as well as moderator skills are essential for the successful implementation of dementia-specific case conferences $[7,10]$.

(a) Dementia and challenging behaviors (half a day): participants: nursing teams (core teams) (open to all staff and guests of the nursing home) aims: i) participants develop an emphatic attitude towards individuals with dementia and use their new knowledge to gain a better understanding about dementia and associated 


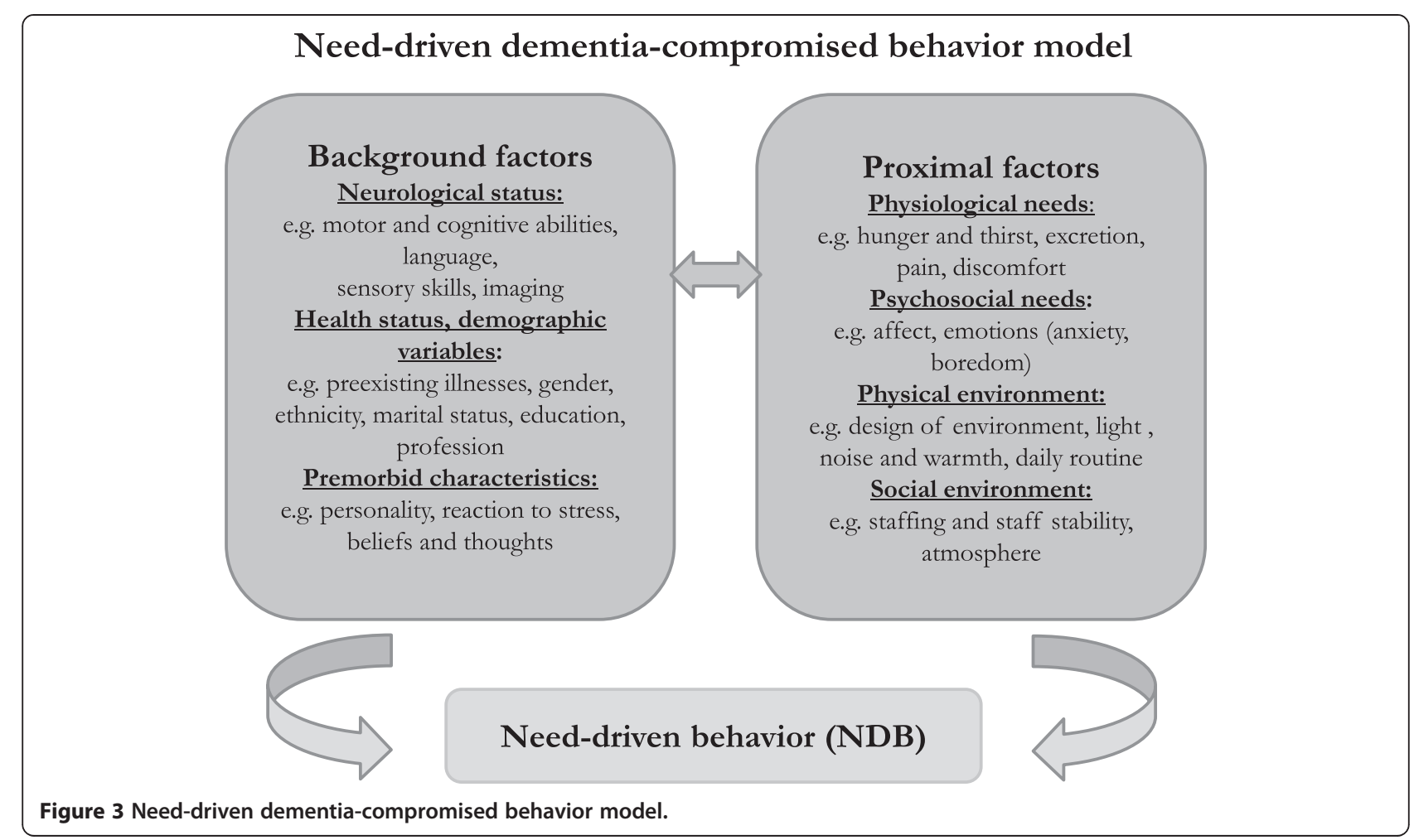

behaviors; and ii) participants distinguish between different forms and stages of dementia and differentiate between dementia and other syndromes, such as delirium and depression.

(b) Moderation skills (two days)

participants: two persons per nursing team (four moderators per cluster)

aims: participants learn the importance and tasks of a moderator in a case conference; basic communication skills that promote a respectful work environment are reviewed; and participants learn moderation skills and how to handle difficult situations during moderation.

Knowledge plays a major role in the implementation of concepts; for example, in the FallDem study, knowledge is circulated [31] among the participating nursing homes, necessitating knowledge brokers [32]. Knowledge circulation refers to the process of transferring research knowledge to practice and is related to the institutionalization of an intervention [33]. Moderators also assists nursing teams by drawing analogic links between solutions determined by reflecting on past cases [34].

(4) Establishment of a steering group:

Each nursing home (cluster) will form a steering group. The steering group should consist of representatives from top management, quality management and members of both nursing teams (core teams). This group will be responsible for the implementation process (such as the designation of responsibilities and creation of structural requirements). It will also be responsible for conducting an assessment of the strengths and weaknesses of the organization in relation to the implementation context. This assessment is important for gaining information about the 'implementation climate' [29]. Based on these results, a specific implementation plan will be developed. Importantly, the steering group will also analyze the impact of the FallDem study on organizational processes [29]. Usually, the following two questions are of interest: 'How relevant is the intervention dementia-specific case conference to the nursing homes?' and 'How much will this improve performance quality and outcome?' [35]. The steering group will meet at least three times and will be moderated by a professional external trainer.

(5) Reminders:

Reminders will be used as an additional means of supporting the implementation process. They will be conducted via telephone prior to the dementiaspecific case conferences. In total, four reminders will be given per nursing team (one per month) 
Table 5 Process structure and key characteristics of both dementia-specific case conferences

\begin{tabular}{|c|c|c|c|}
\hline & WELCOME-IdA & & WELCOME-NEO \\
\hline \multirow[t]{9}{*}{ Process structure } & & \multicolumn{2}{|l|}{ Preparation of case conferences (CCs) } \\
\hline & & \multicolumn{2}{|l|}{ Introduction (welcome, time frame and roles) } \\
\hline & \multicolumn{2}{|c|}{$\begin{array}{l}\text { - Description/quantification of challenging behavior on the } \\
\text { basis of IdA ( } 14 \text { guiding questions) }\end{array}$} & $\begin{array}{l}\text { - Description/quantification of challenging } \\
\text { behavior without assessment (narrative) }\end{array}$ \\
\hline & \multicolumn{2}{|c|}{$\begin{array}{l}\text { - Analyses of triggers and causes of challenging behavior on the basis of IdA } \\
\text { (48 guiding questions) }\end{array}$} & $\begin{array}{l}\text { - Analyses of triggers and causes of challenging } \\
\text { behavior without assessment (narrative) }\end{array}$ \\
\hline & & \multicolumn{2}{|c|}{ Planning of care intervention based on analysis of situation } \\
\hline & & \multicolumn{2}{|c|}{ Closing (for example, personal reflection, what have I learned from the case?) } \\
\hline & & \multicolumn{2}{|c|}{$\begin{array}{l}\text { Post-processing of case conference (for example, responsibility to } \\
\text { transfer results to daily care routines) }\end{array}$} \\
\hline & & \multicolumn{2}{|c|}{$\begin{array}{l}\text { Evaluation of case conference (for example, changes in challenging } \\
\text { behavior due to care interventions and adoption of care interventions) }\end{array}$} \\
\hline & WELCOME-IdA and WELCOI & IE-NEO & \\
\hline \multirow[t]{11}{*}{ Key characteristics } & Participants (core team) & & \\
\hline & 1 moderator & & \\
\hline & 1 keeper of minutes & & \\
\hline & 1 case reporter & & \\
\hline & 2 to 5 reflection partners & & \\
\hline & Location & & \\
\hline & undisturbed room/area & & \\
\hline & Duration & & \\
\hline & 60 to 90 minutes & & \\
\hline & Intervals & & \\
\hline & (at least) monthly & & \\
\hline
\end{tabular}

during the seven months of the intervention phase. They will support the adoption process on the individual level and on the organizational level [35].

(6) Telephone hotline:

A telephone hotline will be established to ensure prompt help with practical difficulties encountered during the organization and performance of the dementia-specific case conferences. This hotline will be maintained throughout the intervention phase. During the phase in which the core team members and moderator act, problems might occur, particularly when they conduct case conferences on their own. The challenge lies in the assumption that the case conference can be conducted according to the study protocol, but in-action heuristic patterns and default options may influence the adoption process [35].

\section{Data collection}

For the process evaluation, a combination of qualitative and quantitative data is gathered that can be subdivided into 14 different data sources (A to N). Table 3 summarizes all of the data that will be assessed in the process evaluation with regard to the intervention. It further provides information about the informant, procedure and time of data collection.

\section{Delivery of intervention to clusters}

The delivery of the intervention to the 12 clusters will be assessed using standardized attendance lists (data source A). The individuals (name, profession and function) participating in the different components of the intervention (I to III) will be documented. Moreover, nonconformities to the training curricula (I to II) will be documented. Deviations will be recorded in relation to the participants, durations, didactic methods and contents of the training units (data source C). Finally, standardized protocols will be written to document each case conference, providing further information regarding their process structures and key characteristics (data source B).

\section{Response of individuals to intervention}

The response of individuals toward the dementiaspecific case conferences will be analyzed in relation to the learning processes of the core teams. A total of 24 
dementia-specific case conferences in a subsample of four nursing teams will be audiotaped (six per team) (data source D) [36]. Two of the selected nursing teams will conduct WELCOME-IdA (12 audiotapes), and the other two will conduct WELCOME-NEO (12 audiotapes). The selection criterion for these four teams will be prior experience in conducting case conferences. The two nursing teams with the most and the two with the least prior experience in conducting case conferences will be selected (also see data source K).

The attitudes of individuals toward the intervention will be assessed first, using a standardized questionnaire (data source E) containing 11 statements pertaining to the use of dementia-specific case conferences. It will be administered to the nursing teams to document changes in attitude toward the intervention throughout the FallDem study (T0 to T6). Each statement will comprise four responses (from 1 =totally disagree to 4 =totally agree). Second, a standardized evaluation sheet will be provided to the participants of the training (I and II) at the end of each session (data source F).

Moreover, four semi-structured telephone interviews [37] with the head nurse of each nursing team (data source G) will be carried out to gain insight into the overall attitudes of the target populations toward the intervention. Finally, semi-structured group interviews [38] will be conducted with all moderators and all 24 nursing teams at the end of the intervention phase (data sources $\mathrm{H}$ and $\mathrm{I})$.

\section{Response of cluster to intervention}

For the response of the clusters toward the intervention, four semi-structured telephone interviews [37] will be conducted with the head nurses of each participating nursing ward during the intervention phase. The head nurse should take part in the dementia-specific case conferences (data source $G$ ). The goal of the interviews with the head nurse will be to assess whether the structured preparation and post-processing of the dementiaspecific case conferences have taken place and whether any changes have occurred due to their implementation. Finally, semi-structured group interviews [38] will be conducted with the steering group, moderators and nursing teams (core teams) at the end of the intervention phase to gain perspective about the overall response of the cluster toward the intervention (data sources H, I and J).

\section{Recruitment of cluster}

To gain insight into the recruitment of the cluster, the recruitment processes of the nursing homes will be documented by the project team (data source N). Additionally, semi-structured telephone interviews [37] will be conducted with each head nurse of the 24 participating nursing wards at the beginning of the FallDem study (data source $\mathrm{K}$ ). The telephone interviews will provide information regarding the reason why each ward has decided to take part in the FallDem study. In addition, semistructured group interviews [38] with each steering group (data source J) and each nursing team (core teams) (data source I) will be conducted at the end of the intervention phase to explore in depth the motivations of each cluster and each ward for participating in the FallDem study.

\section{Recruitment and reach of individuals with intervention}

The recruitment and reach of individuals phase of the intervention will be explored by conducting semi-structured group interviews [38] with the steering groups and moderators at the end of the intervention phase (data sources $\mathrm{H}$ and J). The interviews will address the criteria that clusters have used to allocate core team members. Moreover, attendance lists will be used to assess the individuals in the target population who actually received the different components of the intervention (I to III) (data source A).

\section{Context of intervention}

The context in which the intervention is implemented will first be assessed through a semi-structured telephone interview [37] with the head nurse of each participating nursing ward at the beginning of the FallDem study (data source K). The telephone interview will aim to explore whether nursing teams already have experience in performing dementia-specific case conferences and, if they do, which factors promote or inhibit their performance. Second, the public area of each participating nursing ward will be evaluated with the Dementia Milieu Assessment (DMA) [39]. The DMA assesses the 'dementia-friendliness of environments' and will be conducted during a two-hour observation period from 3 to $5 \mathrm{pm}$. The DMA will be used at the beginning and end of the FallDem study (data source L). Third, a standardized questionnaire will be used quarterly (T0 to T6) to assess the organizational characteristics of the 12 participating clusters and 24 participating nursing wards (such as the size, number of employees, types of living arrangements, staff specialization and characteristics of residents) (data source $M$ ).

To gain insight into the contextual factors that promote or inhibit the implementation of dementia-specific case conferences, all data sources of the process evaluation (A to $\mathrm{N}$ ) will be used and secondarily analyzed. No additional data will be gathered to answer this research question. For the process evaluation of the implementation strategy, seven different data sources (A, C, F, G, H, I and J), which are summarized in Table 4, will be used.

\section{Delivery of implementation strategy to clusters}

The delivery of the implementation strategy to the 12 clusters will be assessed using standardized attendance lists 
(data source A). The individuals (name, profession and function) participating in the steering group meetings and additional in-service training will be documented (3a, b). Moreover, nonconformities to the meeting curricula of the steering group and additional in-service training will be documented. Deviations will be recorded in relation to the participants, durations, didactic methods and contents of the training units (data source $\mathrm{C}$ ).

\section{Response of individuals to implementation strategy}

The attitudes of individuals toward the implementation strategy will be assessed first using standardized evaluation sheets that will be distributed to the participants at the steering group meeting (2) and the additional inservice training $(3 \mathrm{a}, \mathrm{b})$ at the end of each session (data source F). Moreover, four semi-structured telephone interviews [37] with the head nurse of each nursing team (data source $G$ ) will be carried out to gain insight into the overall attitudes of the target populations toward the implementation strategy. Finally, semi-structured group interviews [38] will be conducted with all of the moderators, the steering group and all 24 nursing teams at the end of the intervention phase (data sources $\mathrm{H}, \mathrm{I}$ and J).

\section{Response of cluster to implementation strategy}

For the response of the clusters toward the implementation strategy, four semi-structured telephone interviews [37] will be conducted with the head nurses of each participating nursing ward during the intervention phase. The head nurse should take part in the steering group meeting (data source G). Therefore, the interviews with the head nurse will aim to assess whether the steering group has supported the implementation process of the dementia-specific case conferences and assisted the nursing teams in implementing them in their daily routines. Finally, semi-structured group interviews [38] will be conducted with the steering group, the moderators and the nursing teams (core teams) at the end of the intervention phase to evaluate the overall response of the cluster to the implementation strategy (data sources $\mathrm{H}, \mathrm{I}$ and $\mathrm{J})$.

\section{Recruitment and reach of individuals with implementation strategy}

The recruitment and reach of individuals with the implementation strategy will be explored using semi-structured group interviews [38] with the steering groups (data sources J). The interviews will address the criteria that clusters have used to allocate the members of the steering group and the moderators. Moreover, standardized questionnaires will be used to evaluate who in the target population actually took part in the steering group meetings and additional in-service trainings (3a, b) (data source F).
All semi-structured telephone and group interviews, as well as the audiotapes of the dementia-specific case conferences, will be transcribed verbatim by a professional translation agency and subsequently proofread by one member of the research team prior to data analysis. For the transcription of the interviews, the method of Kuckartz [40] will be used.

\section{Data analysis}

The FallDem study will be evaluated using a mixedmethod design comprising qualitative and quantitative data, which will complement each other, providing a more comprehensive picture of the different concepts under investigation [41]. Guest [42] has noted that consideration of the point of interface (the integration of qualitative and quantitative data) leads to the perspective that 'the timing and the purpose of data integration' are the most important:

'The timing of integration is critically important because it not only conveys when data sets are used with respect to one another but also whether the data sets depend on each other. The purpose of integration denotes the reason for connecting or mixing data sets at each stage of the research process' ([42] page 147).

Bazeley and Kemp have argued that there must be 'interdependence of component approaches during the analytic writing process (...)' ([43] page 69). Simply preparing final conclusions on the basis of different datasets does not mean that the methods have been integrated. Therefore, integration must occur before conclusions are drawn, the results of which will represent 'something that would not have been available without that integration' ([43] page 69).

In this study, data integration will take place on two levels. First, data within the same domain of the process evaluation will be combined to obtain a comprehensive picture of each domain and across domains. For this purpose, integrated analysis will be performed using a DNA double helix method, which compromises sense and antisense strands [44]. Expecting divergent results (within and across domains), this strategy will allow for the determination of concordant findings (the sense strand of the analysis; based on previous studies and expected results) and the consideration of antisense or dissonant findings as counterpoints (the findings of the current FallDem study):

'The divergence of findings can then be used as a promoter (and) can continue in a series of iterations. (...) Thus, reconciliation is sought by undertaking analysis that facilitates a continuous dialogue or exchange of multiple data to understand the phenomena of interest' ([43] page 67f).

Second, data from the three domains, including the delivery of the intervention to the cluster, response of 
individuals to the intervention and response of cluster to the intervention, will be integrated in the statistical analysis of the FallDem effectiveness study through blending [43], meaning that a new variable (time combined with the success of the implementation) will be integrated in the generalized linear mixed-effects model [13]. To achieve this aim, the integration of the data will also be performed in a transformative manner using quantized qualitative coding (the success of the implementation), which can be analyzed in relation to each cluster (also see defining the delayed treatment effect) (Tables 6 and 7).

All quantitative data (standardized questionnaire) will be analyzed using descriptive statistics [45]. All qualitative data will be analyzed using content analysis [50,53], a documentary method $[48,54,55]$ or document analysis [46].

The semi-structured telephone and group interviews will be primarily deductively assessed using the content analysis technique of Mayring [50,53]. The application of the deductive category employs previously formulated, theoretically derived aspects of an analysis (see Tables 6 and 7; theoretical basis) and connects these aspects with the text. In a methodological, controlled assignment, a passage of text is linked with a category. Each deductive category has an explicit definition, example and coding rule with regard to the theory and material and is revised during the analysis [50,53].

The audiotapes of the dementia-specific case conferences will be analyzed using the documentary method $[48,54,55]$, which is a reconstructive analysis tool that allows for case comparisons (key concept). Thus, internal and cross-case comparisons as well as the determination of the comparative knowledge of an interviewer will be possible. Four phases will be implemented as follows: (1) the formation of an outline and detailed paraphrasing that begins prior to transcription with a focus on 'what is said'. To avoid bias, the whole case conference will be transcribed; (2) reflection on interpretation, examining the reconstruction and explication of the orientation frame with a focus on 'how it is said' (during phase 2, internal and cross-case comparisons will be initiated to ensure inter-subjectivity of the results); and (3) the 'stage of case description' (case structure) phase, during which the essential reconstructed elements will be summarized. For phase 1 (what is said), the 'act for team model' will be used [47]. The standardized protocols for the dementia-specific case conferences and the written documentation will be analyzed using documentary analysis [46] (see Tables 6 and 7).

\section{Defining delayed treatment effect}

It can be assumed that a dementia-specific case conference shows its full treatment effect (100\%) when it is delivered over time as intended, is accepted by the nursing team and is adopted by the nursing home. The earliest time point at which a full effect could be expected according to the data is at the transition from training on the job (II) to case conferences without support (III). However, case conferences represent complex interventions that require training and education (as expected, the staff may need more time to learn how to use the case conferences in their daily work routines). Therefore, a delayed treatment effect cannot be excluded (for example, the intervention being only $75 \%$ effective after transition from training on the job (II) to case conferences without support (III)). This information provided by the process evaluation will be important for improving model building using a generalized linear mixedeffects model of the effectiveness study. The delay must be modeled as a fractional treatment effect in the mixed-effects model as described by Hussey and Hughes [21]. To define a possible delayed treatment effect for each nursing home, the data pertaining to the delivery of intervention to clusters, the response of individuals to the intervention and the response of clusters to the intervention will be used.

\section{Ethical considerations}

The Institutional Review Board for Ethics in Research, German Society for Science in Nursing (E-DG-P) has discussed and considered the proposal, entitled Fallbesprechungen bei Menschen mit Demenz (FallDem), Teil II: Interventionsdurchführung (delivered in August 2011), and has approved this study. Informed consent will be obtained from each participant before the start of the trial.

\section{Discussion}

The process evaluation of the FallDem study will provide insights into the implementation process of dementiaspecific case conferences via a cluster-randomized study and help to define the overall success of the implementation. Implementation errors can be explained in cases in which the results of the effectiveness study show no effect or weak effects [56]. Thus, this study overcomes the general criticism that implementation issues have been overlooked in healthcare research on psychosocial interventions in daily residential dementia care [57].

Testing a clinical intervention while gathering information on its implementation in a real-world situation, which is also called an effective-implementation type I hybrid design [58], can further facilitate the incorporation of a new innovation into daily practice [39]. For this study, knowledge about contextual factors that might promote or inhibit the implementation of the dementia-specific case conferences and information about the delivery, acceptability and adoption of the implementation strategy will be gathered. Both types of data will be subsequently used to strengthen the implementation strategy, which in turn will facilitate and reinforce the implementation of the dementia-specific 
Table 6 Data analysis of domains of intervention

\begin{tabular}{|c|c|c|c|c|c|}
\hline Domain & Research question & Data source & Theoretical basis & Method of data analysis & Method of data \\
\hline \multirow{4}{*}{$\begin{array}{l}\text { Delivery of } \\
\text { clusters } \\
\text { (intervention) }\end{array}$} & \multirow{4}{*}{$\begin{array}{l}\text { 1. Was the intervention delivered as } \\
\text { intended for each nursing home (cluster)? }\end{array}$} & \multirow{2}{*}{$\begin{array}{l}\text { attendance lists of in-service training in performing } \\
\text { case conferences (I), training on the job (II) and case } \\
\text { conferences without support (III) }\end{array}$} & \multirow{2}{*}{$\begin{array}{l}\text { - Case conference model } \\
\text { (key characteristics) }\end{array}$} & \multirow[t]{2}{*}{ - Descriptive statistics [45] } & - DNA double helix \\
\hline & & & & & - Blending \\
\hline & & $\begin{array}{l}\text { B standardized protocols of dementia-specific case } \\
\text { conferences }\end{array}$ & $\begin{array}{l}\text { - Case conference model } \\
\text { (process structure and key } \\
\text { characteristics) }\end{array}$ & - Documentary analysis [46] & \multirow[t]{2}{*}{ - Transformation } \\
\hline & & $\begin{array}{l}\text { C written documentation of in-service training in } \\
\text { performing case conferences (I)and training on } \\
\text { the job (II) (deviation from curriculum) }\end{array}$ & $\begin{array}{l}\text { - Curriculum (in-service } \\
\text { training in performing case } \\
\text { conferences (I) and on-the- } \\
\text { job training (II)) }\end{array}$ & - Documentary analysis [46] & \\
\hline $\begin{array}{l}\text { Response and } \\
\text { reach of } \\
\text { individuals }\end{array}$ & $\begin{array}{l}\text { 2. Which learning processes of the target } \\
\text { population took place in response to the } \\
\text { intervention? }\end{array}$ & $\begin{array}{l}\text { D audiotapes of case conferences of four nursing } \\
\text { teams ( } n=24 / 6 \text { per team); } 2 \text { teams using } \\
\text { WELCOME-NEO and } 2 \text { teams performing }\end{array}$ & $\begin{array}{l}\text { - Act for teams, Kasseler } \\
\text { competence inventory [47] }\end{array}$ & - Documentary method [48] & - \\
\hline
\end{tabular}

reach of

individuals intervention?

(intervention)

3. What is the attitude of the target population toward the intervention?

Response of

cluster

4. How was the intervention adopted by

(intervention)

Recruitment of 5. How were the nursing homes (clusters)

cluster sampled and recruited for the FallDem

(intervention) study?

6. Why have the nursing homes participated (or not) in the FallDem study?

WELCOME-NEO and 2 teams peforming WELCOME-IdA

E standardized questionnaire to assess attitudes towards case conferences

- Adoption model [49]

F standardized questionnaire to evaluate in-service - Curriculum (in-service training in performing case conferences $(I)$ and training on the job (II)

training in performing case

conferences (I) and on-the-

job training (II)

G semi-structured telephone interviews to evaluate Adoption model [49] case conferences ( $n=96 / 6$ per nursing team)

H semi-structured group interviews to evaluate - Adoption model [49] intervention $(n=12)$

I semi-structured group interviews to evaluate - Adoption model [49] intervention ( $n=24,2$ per cluster)

G semi-structured telephone interviews to evaluate - Adoption model [49] case conferences ( $n=96 / 6$ per nursing team)

l semi-structured group interviews to evaluate - Adoption model [49] case conferences $(n=24 / 1$ per team)

J semi-structured group interview to evaluate case • Adoption model [49] conferences $(n=12 / 1$ per cluster)

H semi-structured group interview to evaluate case Adoption model [49] conferences ( $n=12 / 1$ per cluster)

$\mathrm{N}$ written documentation of recruitment procedure -

semi-structured telephone interviews to assess 'care as usual' ( $n=24 / 1$ per team)
- Descriptive statistics [45]

- DNA double helix

- Blending

- Descriptive statistics [45] - Transformation

- Content analysis [50]

- Content analysis [50]

- Content analysis [50]

- Content analysis [50]

- Content analysis [50]

- DNA double helix

- Blending

- Transformation

- Content analysis [50]

- Content analysis [50]

- Content analysis [50]

- DNA double helix

- Content analysis [50] 
Table 6 Data analysis of domains of intervention (Continued)

\begin{tabular}{|c|c|c|c|c|c|c|}
\hline & & & $\begin{array}{l}\text { semi-structured group interviews }(n=24 / 1 \text { per } \\
\text { team) }\end{array}$ & & & \\
\hline & & J & $\begin{array}{l}\text { semi-structured group interviews ( } n=12 / 1 \text { per } \\
\text { cluster) }\end{array}$ & - & - Content analysis [50] & \\
\hline \multirow{3}{*}{$\begin{array}{l}\text { Recruitment } \\
\text { and reach of } \\
\text { individuals } \\
\text { (intervention) }\end{array}$} & \multirow{3}{*}{$\begin{array}{l}\text { 7. How were the participants of the } \\
\text { intervention recruited by the cluster, and } \\
\text { who in the target population actually } \\
\text { received the intervention? }\end{array}$} & A & $\begin{array}{l}\text { attendance lists of in-service training in performing } \\
\text { case conferences (I), training on the job (II) and } \\
\text { case conferences without support (III) }\end{array}$ & $\begin{array}{l}\text { - Case conference model } \\
\text { (key characteristics) }\end{array}$ & - Descriptive statistics [45] & - DNA double helix \\
\hline & & J & semi-structured group interview $(n=12)$ & - & - Content analysis [50] & \\
\hline & & $\mathrm{H}$ & semi-structured group interview $(n=12)$ & - & - Content analysis [50] & \\
\hline \multirow[t]{4}{*}{$\begin{array}{l}\text { Context } \\
\text { (intervention) }\end{array}$} & \multirow[t]{3}{*}{$\begin{array}{l}\text { 8. What is the context in which the } \\
\text { intervention is being implemented? }\end{array}$} & K & $\begin{array}{l}\text { semi-structured telephone interviews to assess } \\
\text { 'care as usual' }(n=24)\end{array}$ & $\begin{array}{l}\text { - Case conference model } \\
\text { (process structure and key } \\
\text { characteristics) }\end{array}$ & - Content analysis [50] & - DNA double helix \\
\hline & & $\mathrm{L}$ & Dementia milieu assessment (DMA) & - & & \\
\hline & & M & $\begin{array}{l}\text { standardized questionnaire to assess } \\
\text { organizational and structural characteristics of } \\
\text { nursing homes/nursing wards }\end{array}$ & $\begin{array}{l}\text { - Consolidated Framework } \\
\text { for Implementation } \\
\text { Research (CFIR) [51,52] }\end{array}$ & - Descriptive statistics [45] & \\
\hline & $\begin{array}{l}\text { 9. What contextual factors promote or } \\
\text { inhibit the implementation of the } \\
\text { intervention? }\end{array}$ & $\begin{array}{l}\text { A- } \\
M\end{array}$ & $\begin{array}{l}\text { All data assessed throughout the evaluation } \\
\text { process }\end{array}$ & - CFIR $[51,52]$ & - Content analysis [50] & - DNA double helix \\
\hline
\end{tabular}


Table 7 Data analysis of domains of implementation strategy

\begin{tabular}{|c|c|c|c|c|c|}
\hline Domain & Research question & Data source & Theoretical basis & Method of data analysis & $\begin{array}{l}\text { Method of data } \\
\text { integration }\end{array}$ \\
\hline \multirow{2}{*}{$\begin{array}{l}\text { Delivery of } \\
\text { clusters } \\
\text { (implementation } \\
\text { strategy) }\end{array}$} & $\begin{array}{l}\text { 10. Was the implementation strategy delivered as } \\
\text { intended for each nursing home (cluster)? }\end{array}$ & $\begin{array}{l}\text { A attendance lists of in-service training } \\
\text { (3a, b) and steering group meetings } \\
\text { (4) }\end{array}$ & - & - Descriptive statistics [45] & - DNA double helix \\
\hline & & $\begin{array}{l}\text { C written documentation of in-service } \\
\text { training (3a, b) and steering group } \\
\text { meetings (4) (deviation from } \\
\text { curriculum) }\end{array}$ & $\begin{array}{l}\text { - Curriculum (in-service training in } \\
\text { dementia and moderator skills ( } 3 a \text {, } \\
\text { b) and establishment of steering } \\
\text { group ) }\end{array}$ & - Documentary analysis [46] & \\
\hline
\end{tabular}

\section{Response of}

individuals
(implementation

strategy)

What is the attitude of the target population toward the implementation strategy?

F standardized questionnaire to evaluate in-service trainings ( $3 a$, b) and steering group meetings (4)

G semi-structured telephone

- Adoption model [49]

- Descriptive statistics [45]

- DNA double helix interviews to evaluate implementation strategy $(n=96 / 4$ per nursing ward)

semi-structured group interviews to - Adoption model [49] evaluate case conferences $(n=24 / 1$ per team)

J semi-structured group interviews to - Adoption model [49] evaluate case conferences $(n=12 / 1$ per cluster)

H semi-structured group interview to - Adoption model [49] evaluate case conferences $(n=12 / 1$ per cluster)
Response of cluster

(implementation strategy)
12. How was the implementation strategy adopted by each cluster? semi-structured telephone interviews to evaluate implementation strategy $(n=96 / 4$ per nursing ward)

I semi-structured group interviews to - Adoption model [49] evaluate case conferences ( $n=24 / 1$ per team)

J semi-structured group interview to evaluate case conferences $(n=12 / 1$ per cluster)

H semi-structured group interview to - Adoption model [49] evaluate case conferences $(n=12 / 1$ per cluster)

13. How were participants of the implementation strategy (IS) recruited by the nursing homes, and who in the target population actually received the IS?

- Adoption model [49]

- Adoption model [49]

strategy)
A attendance lists of in-service training $(3 a, b)$ and steering group meetings (4)

H semi-structured group interview $(n=$
- Content analysis [50]

- Content analysis [50]

- Content analysis [50]

- Content analysis [50]

- Content analysis [50]

- DNA double helix

- Content analysis [50]

- Content analysis [50]

- Content analysis [50]

- Descriptive statistics [45]

- DNA double helix 
case conferences in daily routines in nursing homes once the stepped-wedged cluster-randomized study has been completed. The results will be further used to design a successive hybrid III study [58], in which the implementation strategy will be tested and information on the clinical intervention and its related outcomes will be gathered.

Using the results of the process evaluation to design the generalized mixed-effects model of the steppedwedged, cluster-randomized effectiveness study, new methodological pathways in healthcare research will be explored that have not been widely used to date. Previous studies, such as those on the effects of depression and behavior management programs on nursing home residents with dementia $[59,60]$, have considered a full treatment effect directly after the intervention has been rolled out to the cluster. Due to the complexities of both programs, a delayed treatment effect can also be assumed in both of these studies, which may have affected their results.

The limitations of the process evaluation of the FallDem study are also worth noting. The maintenance of dementia-specific case conferences in nursing is an important issue to be explored in a process evaluation; this issue will be only partially addressed in this study. The manner by which individuals and organizations respond to and adopt an intervention may change over time [16], thus, although that topic is beyond the scope of the present study, it may be interesting to determine what will happen during the follow-up-period after the intervention phase of the FallDem study.

\section{Trial status}

The trial was initiated in 2013 and will be completed by the end of 2015. The recruitment of the nursing homes was completed in the fall of 2013. The recruitment of the participating staff will be completed by the end of 2014. Results will be reported at the ends of 2015 and 2016.

\section{Abbreviations \\ CC: Case conferences; CFIR: Consolidated Framework for Implementation Research; DMA: Dementia Milieu Assessment; FallDem: Fallbesprechungen bei Demenz (dementia-specific case conferences); IdA: Innovative dementia-oriented Assessment; IS: Implementation strategy; NDB: Need-driven dementia-compromised behavior; WELCOME-IdA: Witten model of case conferences for people with dementia, the Innovative dementia-oriented Assessment; WELCOME-NEO: Witten model of case conferences for people with dementia, a narrative approach.}

\section{Competing interests}

The authors declare that they have no competing interests.

\section{Authors' contributions}

$\mathrm{DH}$ and $\mathrm{MR}$ designed and wrote the manuscript. $\mathrm{DH}, \mathrm{MR}, \mathrm{IB}, \mathrm{SR}$ and $\mathrm{MH}$ developed the study design. IB, SR and MH assisted with the preparation of the manuscript. RM is responsible for data management. DH coordinates and $\mathrm{MH}$ supervises the project. All authors read and approved the manuscript.

\section{Acknowledgments}

We received funding for this study from the Public Welfare Foundation of North Rhine-Westphalia (Germany), SW-620-6227-Z. The funders had no roles in the study design, data collection, management, analysis, interpretation, manuscript writing or decision to submit the report for publication. We further thank Tina Quasdorf, Rabea Graf and Ute Segscheider-Rosier for their valuable comments. Non-financial competing interests: $\mathrm{MH}$ developed the IdA assessment.

Received: 28 July 2014 Accepted: 1 December 2014

Published: 11 December 2014

\section{References}

1. Moniz Cook ED, Swift K, James I, Malouf R, De Vugt M, Verhey F: Functional analysis-based interventions for challenging behaviour in dementia. Cochrane Database Syst Rev 2012, 2:CD006929.

2. Zuidema S, Derksen E, Verhey F, Koopmans R: Prevalence of neuropsychiatric symptoms in a large sample of Dutch nursing home patients with dementia. Int J Geriatr Psychiatry 2007, 22:632-638.

3. Brodaty H, Arasaratnam C: Meta-analysis of nonpharmacological interventions for neuropsychiatric symptoms of dementia. Am J Psychiatry 2012, 169:946-953.

4. Schmidt SG, Dichter M, Palm R, Hasselhorn HM: Distress experienced by nurses in response to the challenging behaviour of residents - evidence from German nursing homes. J Clin Nurs 2012, 21:3134-3142.

5. Kolanowski AM, Whall AL: Toward holistic theory-based intervention for dementia behavior. Holist Nurs Pract 2000, 14:67-76.

6. Buscher I, Reuther S, Holle D, Bartholomeyczik S, Vollmar HC, Halek M: Das kollektive Lernen in Fallbesprechungen. Theoretische Ansätze zur Reduktion herausfordernden Verhaltens bei Menschen mit Demenz im Rahmen des Projektes FallDem [in German]. Pflegewissenschaft 2012, 03:168-178.

7. Bartholomeyczik S, Holle D, Halek M: Herausforderndes Verhalten bei Menschen mit Demenz verstehen - Die Verbesserung der Versorgung Demenzkranker durch Qualitätsinstrumente [in German]. Weinheim, Basel: Beltz Juventa Verlag; 2013.

8. Reuther S, Dichter M, Buscher I, Vollmar HC, Holle D, Bartholomeyczik S, Halek M: Case conferences as interventions dealing with the challenging behavior of poeple with dementia in nursing homes: a systematic review. Int Psychogeriatr 2012, 24:1891-1903.

9. Bird M, Llewellyn-Jones R, Korten A: An evaluation of the effectiveness of a case-specific approach to challenging behaviour associated with dementia. Aging Ment Health 2009, 13:73-83.

10. Holle D, Krüger C, Halek M, Sirsch E, Bartholomeyczik S: Experiences of Nursing Staff Using Dementia-Specific Case Conferences in nursing homes. Am J Alzheimer's Dis Other Demen 2014. do:10.1177/1533317514552320.

11. Crotty M, Halbert J, Rowett D, Giles L, Birks R, Williams H, Whitehead C: An outreach geriatric medication advisory service in residential aged care: a randomised controlled trial of case conferencing. Age Ageing 2004, 33:612-617.

12. Phillips J, Penny A, West P, Davidson M, Agar M: Does case conferencing for people with advanced dementia living in nursing homes improve care outcomes: evidence from an integrative review? Int I Nurs Stud 2012, 50:1122-1135.

13. Reuther S, Holle D, Buscher I, Dortmann O, Müller R, Bartholomeyczik S, Halek M: Effect evaluation of two types of dementia-specific case conferences in German nursing homes (FallDem) using a stepped-wedge design: study protocol for a randomized controlled trial. Trials 2014, 15:319. doi:10.1186/1745-6215-15-319.

14. van Meijel B, Gamel C, von Swieten-Duijfies B, Grypdonk M: The development of evidence-based nursing interventions: methodological considerations. J Adv Nurs 2004, 48:84-92.

15. Oakley A, Strange V, Bonell C, Allen E, Stephenson J, RIPPLE study team: Process evaluations in randomised controlled trials of complex interventions. BMJ 2006, 332:413-416.

16. Grant A, Treweek S, Dreischulte T, Foy R, Guthrie B: Process evaluations for cluster-randomised trials fo complex interventions: a proposed framework for design and reporting. Trials 2013, 14:15. doi:10.1186/1745-6215-14-15.

17. Moore G, Audrey S, Barker M, Bond L, Bonnell C, Cooper C, Hardeman W, Moore L, O'Cathain A, Tinati T, Wight D, Baird J: Process evaluation in complex public health intervention studies: the need for guidance. J Epidemiol Community Health 2013: 1-2. 
18. Craig P, Dieppe P, Macintyre S, Michie S, Nazareth I, Petticrew M: Developing and evaluation complex interventions: the new Medical Reseach Council guidance. BMJ 2008, 337:a1655. doi:10.1136/bmj.a1655

19. Leontjevas R, Gerritsen DL, Koopmans R, Smalbrugge M, Vernooij-Dassen M: Process evaluation to explore internal and external validity of the "act in case of depression" care program in nursing home. J Am Med Dir Assoc 2012, 13:488. e1-8

20. Voigt-Radloff S, Graff M, Leonhart R, Hüll M, Rikkert MO, Vernooij-Dassen M: Why did an effective Dutch complex psycho-social intervention for people with dementia not work in the German healthcare context? Lessons learnt from a process evaluation alongside a multicentre RCT. BMJ Open 2011, 1:e000094. doi:10.1136/bmjopen-2011-000094.

21. Hussey MA, Hughes JP: Design and analysis of stepped wedge cluster randomized trials. Contemp Clin Trials 2006, 28:182-191.

22. Proctor $E$, Silmere $H$, Raghavan $R$, Hovmand P, Aarons G, Bunger A, Griffey R, Hensley M: Outcomes for implementation research: conceptual distinctions, measurement challenges, and research agenda. Adm Policy Ment Health 2011, 38:65-76.

23. Bleijlevens M, Gulpers M, Capezuti E, van Rossum E, Hamers JP: Process evaluation of a multicomponent intervention program (EXBELT) to reduce belt restraints in nursing homes. J Am Med Dir Assoc 2013, 14:599-604.

24. Nolan L: Caring connections with older persons with dementia in an acute hospital setting - a hermeneutic interpretation of the staff nurse's experience. Int J Older People Nurs 2006, 1:208-215.

25. Kolanowski AM: An overview of the Need-Driven DementiaCompromised Behavior Model. J Gerontol Nurs 1999, 25:7-9.

26. Jung M: Hermeneutik zur Einführung [in German]. Hamburg: Junius; 2001.

27. Ferguson A, Worrall $L$, Sherratt $S$ : The impact of communication disability on interdisciplinary discussion in rehabilitation case conferences. Disabil Rehabil 2009, 31:1795-1807.

28. Halek M, Bartholomeyczik S: 3.4 Assessmentinstrument für die verstehende Diagnostik bei Demenz: Innovatives demenzorientiertes Assessmentsystem (IdA) [in German]. In Assessmentinstrumente in der Pflege. Edited by Bartholomeyczik S, Halek M: Hannover, Schlütersche Verlagsgesellschaft mbH \& Co. KG; 2009:94-104.

29. Aarons G, Horowitz J, Dlugosz L, Erhart M: The Role of Organizational Proocess in Dissemination and Implementation Research. In Dissemination and Implementation Research in Health. Edited by Browson R, Colditz G, Proctor E. Oxford: University Press; 2012:128-153.

30. Luke D: Viewing Dissemination and Implementation Research through Network Lens. In Dissemination and Implementation Research in Health. Edited by Browson R, Colditz G, Proctor E. Oxford: Universitiy Press; 2012:154-174

31. Mitton C, Adair C, McKenzie E, Pattern S, Perry B: Knowledge transfer and exchange: review and synthesis of the literature. Milbank Q 2007, 85:729-768.

32. Ward V, House A, Hamer S: Knowledge brokering: exploring the process of transferring knowledge into action. BMC Health Serv 2009, 9:9-12.

33. Rabin B, Brownson R: Dissemination and Implementation Research in Health. In Dissemination and Implementation Research in Health. Edited by Browson R, Colditz G, Proctor E. Oxford: University Press; 2012:23-51.

34. Glasgow R, Steiner J: Comparative Effectiveness Resarch to Accelerate Translation. Recommendations for an Emerging Field of Science. In Dissemination and Implementation Research in Health. Edited by Brownson R, Colditz G, Proctor E. Oxford: University Press; 2012:72-93.

35. Greenhalgh T, Robert G, Bate P, Kyriakidou O, MacFarlane F, Peacock R: Diffusion of Innovations in Health Service Organisations. A systematic literature review. Oxford: Blackwell Publishing; 2005.

36. Sim J, Wright C: 10 : Recording and organizing data from exploratory studies. In Research in Health Care - Concepts, Designs and Methods. Edited by Julius Sim CW. Cheltenham: Nelson Thornes; 2002:143-150.

37. Burke LA, Miller MK: Phone interviewing as a means of data collection: lessons learned and practical recommendations. Forum Qualitative Forschung 2001, 2:2.

38. Tashakkori A, Teddlie C: Handbook of Mixed Methods in Social \& Behavioral Research. Thousand Oaks, California: SAGE Publications; 2003.

39. Halek M, Dichter M, Quasdorf T, Riesner C, Bartholomeyczik S: The effects of dementia care mapping on nursing home residents' quality of life and staff attitudes: design of the quasi-experimental study Leben-QD II. BMC Geriatrics 2013, 13:53. doi:10.1186/1471-2318-13-53.
40. Kuckartz U: Lehrbuch: Einführung in die computergestützte Analyse qualitativer Daten [in German]. Wiesbaden: VS Verlag für Sozialwissenschaften; 2007.

41. Kelle U, Erzberger C: 4.5 Qualitative and quantitative methods: not in opposition. In A campion to qualitative research. Edited by Flick U, von Kardorff E, Steinke I. London: SAGE Publications; 2004:172-177.

42. Guest G: Describing mixed methods research: an alternative to typologies. J Mixed Methods Res 2012, 7:141-151.

43. Bazeley P, Kemp L: Mosaics, triangles, and DNA: metaphors for integrated analysis in mixed methods research. J Mixed Methods Res 2012, 6:55-72.

44. Kemp L: The DNA of integrated methods, in Annual conference of the Australian Association for Social Reseach. Wollongong: New South Wales, Australia; 2001

45. Scott I, Mazhindu D: Statistics for Healthcare Professionals. London: Sage Publications; 2009

46. Flick U: 22 Using Documents as Data. In An Introduction to Qualitative Research. Edited by Flick U. Los Angeles: SAGE; 2014:352-364.

47. Kauffeld S, Grote S, Frieling E: Das Kasseler-Kompetenz-Raster [in German]. In Handbuch Handlungskompetenzmessung. Edited by Erpenbeck J, Rosenstiel L. Stuttgart: Schäffer-Poeschel; 2007:224-243.

48. Bohnsack R: "Documentary Method". In The SAGE Handbook of Qualitative Data Analysis. Edited by Flick U. London: SAGE; 2014:217-233.

49. Grol R, Wensing M: What drives change? Barriers to and incentives for achieving evidence-based practice. MJA 2008, 180:S57-S60.

50. Mayring P: Qualitative Content Analysis Theoretical Foundation, Basic Procedures and Software Solution. Klagenfurt: 2014. URN: http://nbnresolving.de/urn:nbn:de:0168-ssoar-395173.

51. Damschroder $L$, Aron D: Fostering implementation of health services research findings into practice: a consolidated framework for advancing implementation science. Implement Sci 2009, 4:50. doi:10.1186/1748-5908-4-50.

52. Ilott I, Gerrish K, Booth A, Field B: Testing the Consolidated Framework for Implementation Research on health care innovations from South Yorkshire. J Eval Clin Pract 2013: 19915-19924.

53. Mayring P: Qualitative Inhaltsanalyse. Grundlagen und Techniken [in German] Weinheim: Deutscher Studien Verlag; 2000

54. Evers $\mathrm{H}$ : The documentary method in intercultural research scenarios. Forum Qualitative Research 2009, 10:47.

55. Kohlbacher F: The use of qualitative content analysis in case study research. Forum Qual Res 2006, 7:21

56. Vernooij-Dassen M, Moniz-Cook E: Raising the standard of applied dementia care research: addressing the implementation error. Aging Ment Health 2014, 18:809-814.

57. Boersma P, van Weert JC, Lakerveld J, Dröes R-M: The art of successful implementation of psychosocial interventions in residential dementia care: a systematic review of the literature based on the RE-AIM framework. Int Psychogeriatr 2014, 5:1-17.

58. Curran GM, Bauer M, Mittman B, Pyne JM, Stetler C: Effectivenessimplemenation Hybrid Designs. Med Care 2012, 50:217-226.

59. Leontjevas R, Gerritsen DL, Smalbrugge M, Teerenstra S, Vernooij-Dassen MJ, Koopmans RT: A structural multidisciplinary approach to depression managment in nursing home residents: a multicentre, stepped-wedge cluster randomised trial. Lancet 2013, 381:2255-2264.

60. Zwijsen S, Smalbrugge M, Eefsting JA, Twisk JW, Gerritsen DL, Pot AM: Coming to grips with challenging behavior: a cluster randomized controlled trial on the effects of a multidisciplinary care program for challenging behavior in dementia. J Am Med Dir Assoc 2014, 15:e1-e10.

doi:10.1186/1745-6215-15-485

Cite this article as: Holle et al:: Process evaluation of the implementation of dementia-specific case conferences in nursing homes (FallDem): study protocol for a randomized controlled trial. Trials 2014 15:485. 